\title{
An Analysis of the Effectiveness Farmer Field School (FFS) Approach in Sustainable Rural Livelihood (SRL): The Experience of Punjab-Pakistan
}

\author{
Tahir Munir Butt1*, Qijie Gao1, Muhammad Zakaria Yousuf Hussan² \\ ${ }^{1}$ College of Humanities and Development (COHD), China Agriculture University, Beijing, China \\ ${ }^{2}$ Agriculture Officer, Government of the Punjab, Lahore, Pakistan \\ Email: ${ }^{\text {tahirmunir@uaf.edu.pk }}$
}

Received 11 September 2015; accepted 16 October 2015; published 19 October 2015

Copyright (C) 2015 by authors and Scientific Research Publishing Inc.

This work is licensed under the Creative Commons Attribution International License (CC BY). http://creativecommons.org/licenses/by/4.0/

\section{(c) (i) Open Access}

\section{Abstract}

Farmer Field School (FFS) is a capacity building approach in the Agricultural Extension Approaches (AEA), which provides opportunities to farmers of improving various skills through practicing various techniques by themselves. The review paper is in 2015 to analyze FFS as a strategy for benefiting resource poor farmers from agricultural technologies in Pakistan. Keeping in view the importance of exchange of information, FFS approach is the only approach to agriculture extension in which communication is an integral component because after trained by FFS program and to be expected to become a local agent to deliver the information and techniques of agriculture to other farmers for enhancing the agricultural production, income and improved livelihood. It can be concluded from the study that FFS proves highly beneficial to the farming community due to its capacity building functions.

\section{Keywords}

FFS, AEA, Capacity Building, Sustainable Rural Livelihood (SRL), Social Well-Being

\section{Introduction}

Poverty reduction, rural development and sustainable rural livelihood remained the major aim of various democratic and military governments in Pakistan since independence in 1947. Efforts to ameliorate poverty in many

*Corresponding author.

How to cite this paper: Butt, T.M., Gao, Q.J. and Hussan, M.Z.Y. (2015) An Analysis of the Effectiveness Farmer Field School (FFS) Approach in Sustainable Rural Livelihood (SRL): The Experience of Punjab-Pakistan. Agricultural Sciences, 6, 1164-1175. http://dx.doi.org/10.4236/as.2015.610111 
areas remained fruitless; consequently, significant share of the society was living lower line of poverty. Increase in growth and squeeze in development expenditure have added to increasing poverty [1]. Like other countries of the global world, NGOs in Pakistan play an important role in developing rural areas on sustained basis but there are multiple obstacles that can undermine their capacity to improve the living standards of rural poor. Rural areas are less developed in terms of economic opportunities as well as lack of accessibility to social services [2]. In the world, Pakistan is a 6th position and expected population of 184.35 million. Farming is dominant to financial development in Pakistan, its pay 21.4\% GDP, employments 45\% and pays in the progress of others areas of the country. More than half of country's population live in rural and sub-urban areas and their livelihoods are dependent on agriculture and agro-related activities [3].

There are many definitions, philosophies, and approaches to agricultural extension, and the views of what extension is all about have changed over time. Extension originally was conceived as a service to "extend" research-based knowledge to the rural sector to improve the lives of farmers. Agricultural Extension can be defined that support and facilitate people engaged in agricultural production to solve problems and to obtain information, skills, and technologies to improve their livelihoods and well-being [4].

For the uplift of living standard of rural people and introduce of new technologies in agriculture, Government of Pakistan both at federal and provincial level has tested many Agricultural Extension Approaches, Systems for agricultural production and sustainable rural livelihood during in different regimes e.g. Extension Programs in the Punjab, The Village Agricultural and Industrial Development (V-AID) Program, Integrated Rural Development Program (IRDP), The Basic Democracies System (BDS), Rural Works Program (RWP), Peoples Works Program (PWP), Traditional Agricultural Extension System, Training and Visit (T\&V) System, Devolution Plan, Pakistan Poverty Alleviation Fund (PPAF), Benazir Income Support Program (BISP), Pakistan Bait-ul-Mal (PBM), Zakat funds, Public-Private Partnership but unfortunately all of them finished one after the other due to many reasons e.g. lack of motivation among extension staff and farmers, Governmental instability, corruptions in the utilization of funds, jealously and exploitation, protectiveness among allied departments are the main reasons of the failure of these programmes to the livelihood of the rural poor farmers for poverty moderation. Mostly Extension System in Pakistan is highly top down and the participation of end users which are farmers is negligible since independence [3] [5]-[7]. Further, to meet the growing needs of increasing population, adaptation of advance agriculture techniques and farming methods are imperative. Improvement in agriculture sector can meet the growing demand of food increasing population as well as helpful for poverty elimination and sustainable rural livelihood in Pakistan. But due to low literacy rate and lack of awareness about farming practices, the average yields in Pakistan remain lower than those of the develop countries [7]

Many short-term plans were launched in the mid-1980s; for example, during 1985-88, the prime minister's five development points were introduced to 4 promote the welfare and prosperity of rural communities. This gained had success because of strong political commitment but came to an abrupt end as a result of a change in government [5].

\section{Current Status of Knowledge}

All the nations have approved models for progress in agriculture to address the native problems and the capacity of rural communities. Reference [8], empirically observed the association between socioeconomic measures of deprivation; such as food insecurity, landlessness, unemployment, human underdevelopment and incidence of violent conflict. She argued that landlessness and food insecurity seem to be positively associated with the probability of violent attacks across districts in Pakistan also.

The most important challenge in Pakistan is how to develop agriculture extension approaches that go beyond extending technical knowledge to the producers, to play a leading role in helping small scale farmers, organize themselves for sharing production and protection technologies, marketing and advocacy in such a way that empower the farming community [9]. Pakistan's populace is living lower poverty line about $60 \%$, a report World Development Indicators (WDI) 2013, the global poverty line is two dollars a day or an income of Rs 200.00 per day. According to the report displays that $21 \%$ of Pakistan's populace exists lower $\$ 1.25$ per day [10]. The main causes of income in rural peoples in Pakistan are farming, salaries etc. According to the report of Pakistan Economy Survey [3] overall agriculture sector showed the growth of agriculture stood at 3.3\% as compared to $3.5 \%$ in the last year. This production impact not only the economy of the country but also on the livelihood of those farmers. The area and intensity of crops under cultivation has gradually increased and has almost double over the period of time. However yield per unit area and net income is still very low as against the potential. 
In agriculture sector, agriculture extension is one of the main institutional components having aim to improve the living conditions of rural poor through transfer and exchange of information and plays a prominent role in agriculture as well as overall rural development and poverty moderation [11]-[15]

The FFS approach is action-learning oriented where farmers are allowed to perceive examine and make substitute assessment about their crop yield [16] [17]. The main apprehension of the FFS investigation is to test the performance creativities in endorsing Agricultural technologies to alleviate the poverty reduction and sustainable rural livelihood. Reference [18] concluded that gains in yield and knowledge can be achieved through participation of farmers. According to [17] founded that FFS members were not sharing these practices with other farmers which vulnerable the sustainability of FFS programs in Sindh-Pakistan.

A publication in World Bank-2012, on "Strengthening Agricultural Extension and Advisory Systems" FFS are particularly suited for learning complex management skills, like natural resource management, diversifying production and accessing markets to increase rural incomes [19]. The FFS is a process and not a goal. It brings farmers together to carry out collective and collaborative inquiry with the purpose of initiating community action in solving community problems. Field Schools aim to: Empower farmers with knowledge and skills to make them experts in their own fields; Sharpen farmers' ability to make critical and informed decisions that render their farming profitable and sustainable; Sensitize farmers into new ways of thinking and problem solving; Help farmers learn how to organize themselves and their communities.

Reference [20] state the historical context out of which FFS approach emerged was dominated by the agricultural projects of the green revolution. However, numerous programmes and approaches on the part of the government of Pakistan, such as rural development programmes [21], rural support programmes and the Social Action Plan, could not create much of a positive impact on people's lives [22] [23]. According to reference [7] effective implementation of Agricultural Extension approach, per acre crop yields can be improved and provide more food to deal with food security issue and uplift the life standards of poverty struck farming communities and prompt knowledge of new technology.

Agriculture pays to growth as an economic action, as a livelihood, a source of environmental facilities, creation the sector a single tool for growth. Agricultural production is significant for food security because it's a source of revenue for the majority of the rural poor. Agriculture is a basis of livelihoods for predictable $86 \%$ of rural people. Its sector has a strong record in growth of Agriculture has special powers in moderation of poverty and sustainable rural livelihood [24].

According to the report [25] agriculture is the primary source of livelihood and in the vision for the period 2010 to 2020, "world free of hunger and malnutrition where food and agriculture contribute to improving the living standards of all, especially the poorest, in an economically, socially and environmentally sustainable manner". FAO also mentioned that eradication of poverty and the driving forward of economic, social progress for all and through increased food production to enhanced rural development and sustainable livelihoods and focus also on capacity development of rural communities.

At the time of planning the present review of study entitle "An analyze of the effectiveness of Farmer Field School (FFS) approach in sustainable rural livelihood: The experience of Punjab-Pakistan" will be helpful in designing more flawless program that will ultimately provide better results for Agricultural Development and Sustainable Rural Livelihood of the rural poor farmers for poverty alleviation in Punjab Province-Pakistan. This study will also provide an alternative framework for government, policy makers, institutions, NGO's, agricultural extensionist researchers and donor agencies on the most effective strategy for sustainable \& improved livelihood, poverty alleviation, a proper analysis and evaluation of the existing ones. Further, for overhauling and rejuvenating extension system in Punjab-Pakistan.

The most important matter of concern especially in developing countries regarding rural development is to enhance agricultural production on sustainable basis in order to provide sufficient food for an always growing populace and to eliminate rural poverty [26]-[28]. In the world for most consequences of agricultural development on rural livelihoods is not only raising their income but also generation of labour and capital [29]-[31]. Reference [32] showed that $1 \%$ growth in per capita farming production directed to a $1.61 \%$ rise in the profits for the poorest $20 \%$ of the populace. Pro-poor relation is created by the things of productivity/growth on the food amounts [33]. Reference [34] discovery that development in farming has been an important factor in decreasing rural poverty in Indonesia. Its means that agricultural development has directly with contribute to a rapid reduction in poverty and improved livelihood. Agricultural extension, education, and advisory extension services are a thoughtful of addressing rural poverty because some organizations must a directive to relocation 
technology, farmers in problem resolving, and enable farmers to become gain more agricultural knowledge, skills with production and sustainable rural livelihoods [35]. The literature is reviewed to better understand the concept of FFS, and the analysis of the effectiveness of FFS in sustainable rural livelihood.

\subsection{Poverty}

One of the fore most progress problems facing the world is increasing of poverty. It is predictable that 1.3 billion persons living on less than one dollar per day, and one billion persons cannot meet basic necessities [36]. The World Bank mention that worldwide poverty line of \$1.25 per day however in China approved line of poverty for rural populace is 785 Yuan per day, equal to $\$ 0.57$ in 2005 PPP dollar but the fact poverty reduction still remains serious for China, still 254 million poor in 2005, the second largest number in the world, after India [37]. In the universe every human beings needs the basic facility or necessary things of life, such as food, schooling and health care, for daily life of the person. The particularly needed things and services which are not available easily in life is poverty. Poverty means food shortage, lack of access to schooling, health facilities [38]. In Pakistan, a poverty area was $42.28 \%$ in the 1960 's but rural poverty decreased in 1970's because private investment in agriculture reached its peak [39] [40]. Decreasing in poverty continuous in the 1980's mainly due to improved growth in agriculture sector [39]. Poverty is defined as the inability to attain a minimal standard of living. Poverty can be alleviated only if a country use 50 percent of its total public investment for rural sector such as for agriculture and agro-based industry, irrigation, rural infrastructure etc. consistently for the 10 years and within 6 year country will be in position to get fruitful results regarding poverty alleviation under the era of globalization [2].

The impact of agriculture on poverty alleviation be determined by several effects e.g. result of production in the agriculture sector is to increase revenue levels of those working in this sector [41] [42]. Reference [43] also initiate development in agriculture and rural economy had been extremely helpful to decreasing rural poverty in India. Reference [44]-[46] found that higher yields advanced non-farm output and lower increase were all poverty decreasing in India.

The Ghana Government is devoted to decreasing poverty through agricultural and rural development. Reference [47] showed that Ghana mutual Growth and Development Agenda (GSGDA) stresses the need to focus on agriculture.

\subsection{Sustainable Rural Livelihoods (SRL)}

Livelihood "the means of gaining a living" [48]. According to reference [28] "A livelihood comprises the capabilities, assets (including both material and social resources) and activities required for a means of living. A livelihood is sustainable when it can cope with and recover from stresses and shocks and maintain its capabilities and assets both now and in the future, while not undermining the natural resource base."

Reference [49] showed in the perspective three words "sustainable, rural and livelihoods" meaning a specific methodology as for a people-oriented progress that initial argument the rural realities of poor people. A livelihood is sustainable when it can manage with and improve from pressures and shocks, maintain or enhance its capabilities and assets, while not discouragement the natural resource base. The term "Sustainable Livelihood" has been well-defined in a different of ways by several authors in the context of NRM, Poverty Alleviation and Agricultural Development. There are certain resemblances and likewise contradictions in these explanations, depending on the diverse situations in which examines are undertaken. The maximum similarities, a sustainable livelihood can be defined as people's capacity to sustain a living by surviving shocks and stress and enhancing their quality of life on a long-term basis without threatening the livelihood possibilities of others [50]-[52].

The concept of sustainable livelihoods is increasingly important in research about regional development, poverty alleviation, rural agricultural development and rural resource management [50]-[54]. A Sustainable Livelihoods approach to development demands a more holistic understanding of poverty, and of the linkages between different livelihoods components. Rural people's ownership of and access to certain livelihood assets may have a positive impact on their strategies for coping with vulnerabilities and risks [55].

Further the strong encouragement for sustainable livelihoods methods in progress from the 1990s [53] [55][57] and various development organizations initiated to advocate livelihoods approaches as vital to their programming, and even organizational arrangements. FSR (Farming Systems Research) was stimulated in the developing countries, with the purpose of getting a more integrated, systems perception on farm problems and im- 
proved livelihood. Advanced, AEA (Agro-Ecosystem Analysis, RRP (Rapid Rural Appraisal) \& PRA (Participatory Rural Appraisal) approaches [58] [59] were further to the repertoire, increasing the variety of approaches and styles of field engagement in the aspect of Livelihood.

\subsection{Capacity Building}

There are several definitions, each reflecting its own particular bias or orientation. Some describe capacity building as an approach or process to achieve a goal, such as poverty reduction, while others see it as an objective in itself, such as the development of individual or organization effectiveness. Capacity is understood as the ability of people, organizations and society as a whole to manage their affairs successfully. Capacity is the proven ability of key actors in a society to achieve socio-economic goals on their own. In short, Capacity = Institutions + Leadership + Resources + Skills + Practices-Constraints (World Bank, 2006). Capacity is the ability of individuals, organizations and societies to perform functions, solve problems, and set and achieve goals. Capacity development entails sustainable creation, utilization and retention of that capacity to reduce poverty, enhance self-reliance, and improve people's lives [60]. Capacity means helping women, men and children in developing countries, their communities and institutions, to acquire the skills and resources needed to sustain their own social and economic progress [61]. According to reference [62], there is a modification in sense of capacity and capability. Capability is a competence defined as the knowledge, skills and attitudes of individuals and capacity is defined as the general ability of individuals to carry out the tasks required to achieve their goals.

\section{Why Capacity Building is Important for Sustainable Rural Livelihood}

Capacity building at local, provincial and nationwide levels has become central to the goals of progress of governments working in developing countries. Reason in past failures of rural development approach to minimize poverty and empower local people to improve their livelihoods. Organizations persuaded to handover only capital and modern technology to farmers or provide formal education to rural communities [63]. These actions were directed by Government, NGO, Researchers and Extension Officers, with slightly participation of local people. After finished the project, local people could not continue to recover themselves and grow their groups. Reference [64] mentioned additional comments that "investment alone cannot lead to the desired level of improved livelihood". Therefore, building the capacity of local people, groups and organizations is vital because they must have the ability and responsibility to resolve their problems and develop their communities. Development of the projects are often expensive, donor-driven, be contingent on external specialists and don't follow the countrywide significances of the country [65]. According to reference [66] therefore, educating the capacity building of individuals, groups, organizations and groups is necessary for rural development, livelihood, poverty relief and environment security.

\subsection{Farmer Field School (FFS)}

The basic features: FFS is empirical, participatory, field observation, experimental base and learner center; FFS meeting comprises by three actions: analysis of the agro-ecosystem, special problem, and a group; FFS members conduct a study comparing IPM (Integrated Pest Management) with non-IPM plans, FFS has between 25 and 30 farmers participate; FFSs comprise a Field Day in which farmers participate in presentations about IPM and their interest, finally follow-up activities in FFS for sustainable livelihood. The training organized under FFS approach assists farmers in improving their capacity to make critical decisions that may make their production systems more productive, profitable, and sustainable livelihood [67]. The FFS is participatory methods of learning, technology adaptation, and dissemination based on adult learning principles such as experimental learning. The FFS approach was established in the late 1980's in Asia. The FFS approach provides a plate forum for farmers to strength their knowledge and field management decision skills through a process of hands-on filedbased. The FFS is a group education method that has been used by Government, NGO's and Worldwide organizations to educate farmers with special highlighting on Integrated Pest Management (IPM). Firstly FFS were planned and launched by the United Nations FAO in Indonesia in 1989 [20] [68]. The FFS also enhances group collaboration, participation within farmers. FFS is a participatory approach for rural progress and poverty alleviation through in Agricultural production. The FFS method has one of the greatest inspiring path proceedings in participatory community approaches, with two million growers graduated on the subject of agriculture in IPM for the duration of the last 15 years in Asia and FFS had a significant impact on reducing the use of pesticides 
and increasing yields [69]. FFS is a podium ("without wall schools”) for educating decision-making capability and inspiring for the grower improvement for sustainable agriculture [70]. FFS offers community-based, 20 - 25 farmers through self-discovery and sharing learning principles [71]. FFS is non-formal education where groups of farmers meet weekly with extension worker. FFS is a participatory approach of knowledge is used for the dissemination of knowledge. The farmer field school (FFS) approach that promotes group learning optimally from field observation and experimentation based on principles of adult education and training to farmers is seen as the single approach of agriculture extension that can meet these goals [72]. FFS is also use in the education which uses practical knowledge approaches to build farmers' proficiency [20].

According to reference [73], FFS uses a participatory approach to assist farmers to develop their capabilities in analytical skills, critical thinking, and creativity so that farmers can make better decisions. In the developing countries highlights the signification of agriculture in poverty decrease policies, because most of the rural populace hopes directly or indirectly on agriculture [41]. Reference [74] stated that in Farmer Field School (FFS) approach; the most important purpose of FFS participatory approach was empowering farming community especially resource-poor farmers. The FFS is the awareness gained from these activities enables participants to create their individual locally results about crop production through management practices [20] [75]. Farmers are facilitated to conduct their own research, diagnose and test problems, and come up with solution. FFS training program helps farmers develop analytical skill, critical thinking, and creativity, and learn to make better decisions. Through group interaction, attendees sharpen their decision making abilities and their leadership, communication and management skills [12].

According to the FFS approach aim to increase the technical and social competences of farmers concerning crop or livestock with confidence [47]. The Government of Ghana approved FFSs as a major approach for executing the Food Security and Poverty Reduction Programmes. Consequently, the Ministry for Food and Agriculture (MOFA) officially predictable FFSs as a National Extension Method. Through the FFS, farmers become better partners for researchers and extension workers. According to reference [76], FFS approach improve livelihoods/human well-being (increase the crop productivity, income from farming also increased); poverty alleviation; improve sustainable land management (improved productivity of agricultural crops; improve soil properties and soil/reclamation conditions).

Majority of farmers in Pakistan are illiterate and unaware of modern agricultural technologies. In this critical situation agriculture extension agencies need to play crucial role for the better production and better living standard of life. FFS to encourage based-learning, decrease reliance of the farmers on outside contributions improve their result creation through exploration, decrease price of production and encourage sustainable agriculture practices and technologies.

\section{Framework}

Several institutions including the Food and Agricultural Organization of United Nations, the Overseas Development Institute, the Institute of Development Studies, and the European Union and non-governmental organizations such as Cooperative for Assistance and Relief Everywhere Inc. and OXFAM and donors (e.g. the UK Department for International Development (DFID) and the United Nations Development Programme (UNDP) have developed frameworks to analyses sustainability of livelihoods. Most of these frameworks are reasonably similar, except for UNDP's analytical framework [52]. The plan of this study is on the said literature evaluation that FFS effectiveness (in-depended variable) on knowledge/Technical, Attitude/Socially and Performance/Politically in helping agricultural production and sustainable rural livelihood practices are correlated as dependent variables. The sustainable livelihoods framework presents the main factors that affect people's livelihoods, and typical relationships between these. It can be used in both planning new development activities and assessing the contribution to livelihood sustainability made by existing activities and emphasizes the multiple interactions between the various factors which affect livelihoods [73].

FFS training aims to affects farmers knowledge, which can be interpreted broadly to include the possession of analytical skills, critical thinking, and the ability to make better decisions, as well as familiarity with agricultural practices and understanding of interaction within the agricultural ecosystem. Improved knowledge, attitude and performance are in turn reflected in farmer cultivation procedure, input decisions and crop yields.

In the livelihood assets: Conceptual framework (Figure 1) draws attention to measured changes in the different factors that contribute to livelihoods; five capital assets variables (Personal, Cognitive Psychology, Physical, 


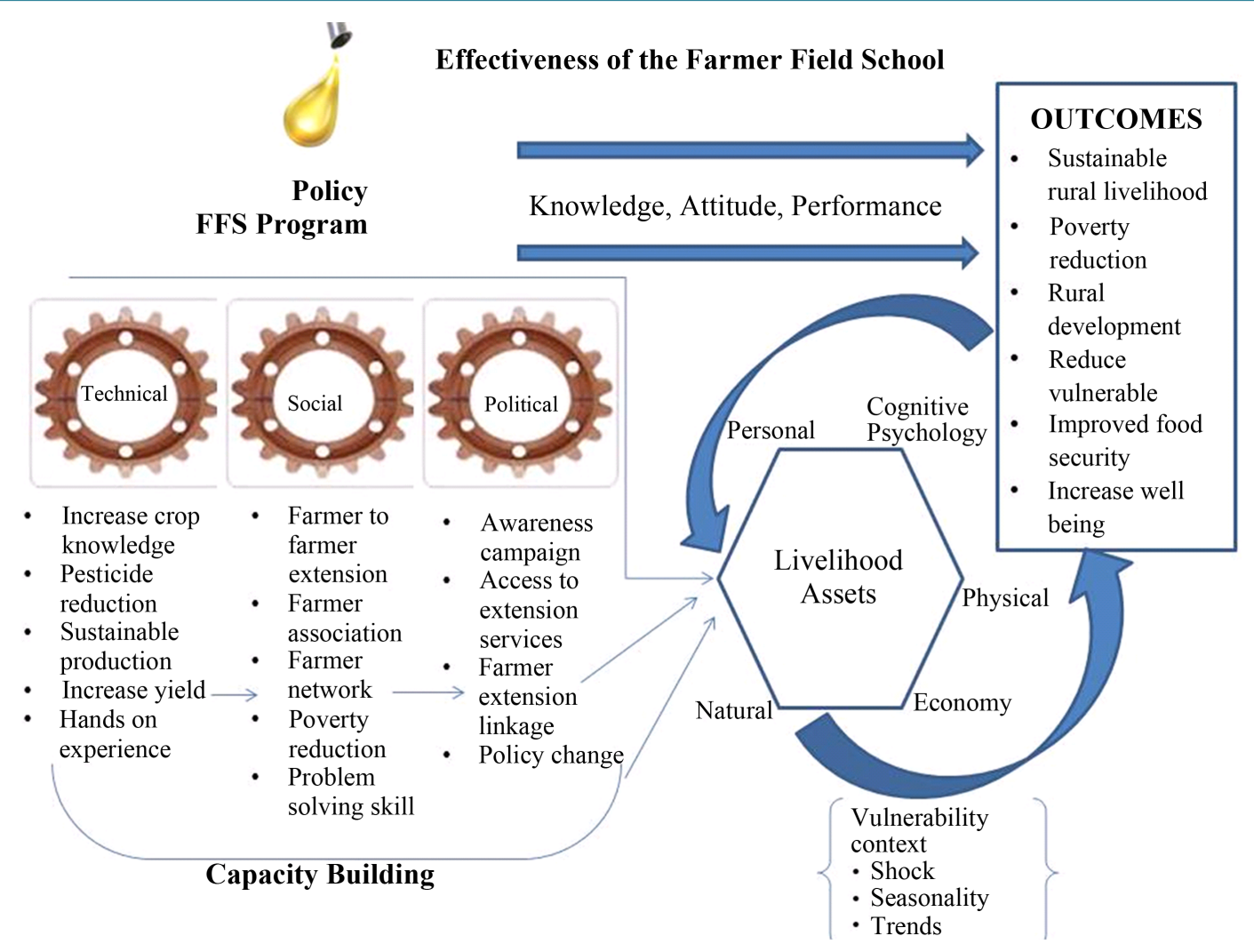

Figure 1. Author computation.

Natural and Economy), institutional process and organizational structure, resilience or vulnerability of livelihoods, livelihood strategies and outcomes. Each capital asset consists of key indicators, for example, Personal variables like human assets such as age, education, vocational training, extension services, health facility, skill and farm experience are assumed to inspiration the dependent variables knowledge, attitude and performance. The cognitive psychological variables like social assets inspiration, creativity, behavior about sharing information with relative/neighbors, achievement, interpersonal, confidence, social participation, and farmer organization are also imagined to impact the dependent variables. In physical assets variables like road/transport, water and supply, Agricultural Machinery, Market assessment are presumed to stimulate the dependent variables. In natural assets like land/tenure, forests etc. are expected to inspire the dependent variables. In economy/monetary assets like income from crops, vegetables and fruits, labor works, agricultural loans (bank, society etc.), house loans, insurance, cash and livestock are anticipated to affect the dependent variables.

A single asset can generate multiple benefits, for example, if a household has secure access to land, they are also likely to be well endowed with financial assets, as they can use the land for productive purposes and to secure loans [50] [54] [74]. Amongst the different assets, natural assets are quite valuable to those people who obtain their livelihoods from resource-based activities such as farming, fishing and gathering from forests, Physical assets are very important, for example, without transport services inputs such as fertilizer and planting materials may not be easily available for farming and this may result in a decrease in agricultural yield, it is then difficult and expensive to transport produce to the market. Using five assets, people engage in various livelihood strategies in order to achieve livelihood objectives [50] [53] [77].

\subsection{Livelihood Strategies}

The study of livelihood strategies will focus improvement in livelihoods through FFS program and use capacity building dimensions (technical, social and political) variables on different core activities; cropping (farming), keeping of livestock, pesticide reduction, problem solving skills, increase yields and labor etc. under the Government policies and vulnerability context (shocks, seasonality and trends). 


\subsection{Vulnerability Context}

In the understanding of the livelihood approach, 'vulnerability' consists of shocks, trends, and seasonalities, or, in other words, "the external environment in which people exists" [77].

1) Seasonality-Respondents have been asked which months of the year are the most difficult ones in order to provide adequate food for their household.

2) Trends in purchasing power, food security, health, and household size Respondents' opinions on the development of their household's purchasing power vary. In many cases, families had to reduce their food consumption, or take cash or kind loans.

Shocks-Shocks are a key element in the vulnerability context. They are usually sudden events that have a significant impact—usually negative—on livelihoods. They are irregular.

\section{Conclusions and Suggestion}

The goal of the study was to provide robust evidence for policymakers, donors, farmers, and implementation actors on whether and how the FFS approach can contribute to poverty alleviation and productivity. We set the following specific objectives:

a) Examine participation in the FFSs, especially the extent to which poor people, women, and other marginalized groups take part in the schools.

b) Examine the effects of farmer field schooling on outcomes such as poverty, gender, and productivity, and the role that household-capital-endowment-level social characteristics have on access and use/maximization of benefits of the FFS approach. Henceforth we summarize the findings on each of the objectives, and then offer some policy recommendations based on those results.

As the preceding italicized statements suggest, the following policy implications may be drawn as a result of this study:

1) It is important to support farmer organizations as a major vehicle for farmer development. In this study, farmer groups proved to be important in helping farmer's access rural services. This is in line with other research in the region.

2) The FFS program not only allowed women to participate but led to significant benefits in terms of income and crop and livestock production in Pakistan region. According to literature, Women constituted 50 percent of participants in the different projects. The FFS program appeared to be more beneficial for female-headed households than for male-headed households. FFS programs can be used to provide agricultural extension services to women, who contribute the most in agricultural production and yet have poor access to agricultural extension services compared with male farmers. It has been shown that women gain greater benefits than men when they have access to the same inputs. The FFS approach can thus be used to target women farmers and female-headed households while still reaching men.

3) The FFS program not only allowed people with low education to participate but led to significant benefits in terms of income and crop and livestock productivity. The FFS program can be used to target low-education groups. This is contrary to the conventional wisdom, which says that FFSs are better suited for people with higher education levels, because of the semiformal nature of the education that takes place. Apparently the demonstration sites, experiential learning methods, group approaches, and other factors make up for this and allow low-literacy people to participate and benefit.

4) The FFS approach had the most beneficial effects on farmers with medium-size land areas. The program showed limited impact on farmers with the poorest (smallest) land size, but it had a significant impact on farmers with medium-size land areas (relative to the area). This is also important when targeting groups. Farmers with the smallest land size may not have enough land to experiment on, or they may be too busy working on other people's land to be able to participate fully in the FFS. Farmers with larger land size may not have the need to participate in programs such as FFS that are geared toward reducing poverty. The time needed to participate in the FFS may also prohibit larger-scale land owners from participating.

5) It is important to invest in infrastructure in rural areas. The study showed that in most cases, farmers who were near tarmac roads were more likely to participate in an FFS. Roads are important in ensuring agricultural services even for remote areas. Roads reduce the cost of transport to markets and other urban centers, and they allow farmers to get produce to market more quickly and cheaply.

6) The FFS program has the potential to be effective under different agro-ecosystems, livelihoods, and farm- 
ing systems. As increased focus is put on extension in general and FFSs in particular, it is more important than ever to implement programs and policies that suit the local conditions, including the policy environment, farming systems, and capacity of service providers and communities.

\section{References}

[1] UNDP (2010) Beyond the Midpoints: Achieving the Millennium Development Goal. United Nations Development Programme, New York.

[2] Jianxiu, G. (2006) The Role of NGOs in the Social Welfare. Canadian Social Science, 2, 15-18.

[3] Government of Pakistan (2013-2014) Economic Survey 2013-14: Government of Pakistan, Economic Advisor’s Wing. Finance Division, Islamabad.

[4] Birner, R., Davis, K., Pender, J., Nkonya, E., Anandajayasekeram, P., Ekboir, J., Mbabu, A., Spielman, D., Horna, D., Benin, S. and Cohen, M. (2006) From "Best Practice" to "Best Fit": A Framework for Analyzing Pluralistic Agricultural Advisory Services Worldwide. ISNAR Discussion Paper No. 5. NW, Washington DC. IFPRI.

[5] World Bank (2007) Pakistan Promoting Rural Growth and Poverty Reduction. Report No. 39303-PK. Sustainable and Development Unit, South Asia Region, World Bank, Islamabad.

[6] Khan, A.R. and Khan, A.N. (2001) An Overview of Rural Development Programmes and Strategies in Pakistan. Journal of Rural Development \& Administration, 33, 22-29.

[7] Abdullah, M., Xia, L.C., Li, J., Ghazanfar, S., Mehmood, Y., Ishaq, M.N. and Saud, S. (2014) Effectiveness Comparison Between the Farmers Field School and the Training \& Visit Approaches of Agricultural Extension in Two Districts of Pakistan. American-Eurasian Journal of Agricultural \& Environmental Sciences, 14, 33-39.

[8] Malik, S.M. (2011) An Empirical Investigation of the Relationship between Food Insecurity, Landlessness, and Violent Conflict in Pakistan. Pakistan Institute of Development Economics, Islamabad.

[9] David, S. (2007) Learning to Think for Ourselves: Knowledge Improvement and Social Benefits among Farmer Field School Participants in Cameroon. Journal of International Agricultural and Extension Education, 14, 35-49. http://dx.doi.org/10.5191/jiaee.2007.14203

[10] Zaheer, A. (2013) World Bank, 2013 by Newspaper Business Recorder 19 May, 2013

[11] Eicher, C.K. (2001) Africa’s Unfinished Business: Building Sustainable Agricultural Research Systems. Staff Paper 20001-10, Department of Agricultural Economics, Michigan State University, East Lansing.

[12] Anderson, R.J. and Feder, G. (2003) Rural Extension Services. World Bank Policy Research Working Paper 2976, Agriculture and Rural Development Department, World Bank, Washington DC.

[13] Farooq, A. and Ishaq, M. (2005) Devolving the Farm Extension System, P: III. Economic and Business Review. Daily Dawn, Karachi.

[14] Obaa, B., Mutimba, J. and Semana, A.R. (2005) Prioritizing Farmers' Extension Needs in a Publicly-Funded Contract System of Extension: A Case Study from Mukono District, Uganda. Agricultural Research \& Extension Network, Network Paper No. 147.

[15] Photakoun, V., Millar, J. and Race, D. (2010) Evaluating Capacity Building Methods to Strengthen Livestock Extension Outcomes in Laos. Extension Farming Systems Journal, 5, 91-100.

[16] Kingsley, M. (1999) Season of Learning: From Field Schools to Farmers Organized Management: Extension and Advocacy. Farmer and NGO Experiences in Indonesia. World Education, Jakarta.

[17] Siddiqui, A.A., Mirani, Z.A. and Bukhari, S.S. (2012) Impact of Farmer Field School Training on Farmers’ Knowledge and Skills regarding Recommended Agro-Ecological Sound IPM Practices in Selected Districts of Sindh. Pakistan Journal of Agriculture, Agricultural Engineering and Veterinary Sciences, 28, 186-198.

[18] Khan, M.Z., Nawab, K. and Khan, M.A. (2006) Weeds Related Professional Competency of Agricultural Extension Agents in NWFP, Pakistan. Pakistan Journal of Weed Science Research, 12, 331-337.

[19] Swanson, B.E. and Rajalahti, R. (2010) Strengthening Agricultural Extension and Advisory Systems: Procedures for Assessing, Transforming, and Evaluating Extension Systems. Agriculture and Rural Development Discussion Paper 45, The International Bank for Reconstruction and Development/The World Bank, Washington DC.

[20] Pontius, J., Dilts, R. and Bartlett, A. (2002) From Farmer Field School to Community IPM. Ten Years of IPM Training in Asia. FAO Community IPM Program, Jakarata.

[21] World Bank (2004) Social Mobilization and Enhancing Livelihoods. World Bank, Washington DC.

[22] Qadir, A. (2002) Pakistan in Civic Entrepreneurship: A Civil Society Perspective on Sustainable Development. Gandhara Academy Press, Islamabad. 
[23] Shahbaz, B., Shah, Q.A., Suleri, A.Q., Commins, S. and Malik, A.A. (2012) Livelihoods, Basic Services and Social Protection in North-Western Pakistan. Working Paper 5, SDPI.

[24] World Bank (2008) World Development-Report: Agricultural for Development. The World Bank, Washington DC.

[25] FAO (2013) Agricultural Livelihoods and Food Security Impact Assessment and Response Plan for the Syria Crisis in the Neighboring Countries of Egypt, Iraq, Jordan, Lebanon and Turkey. FAO, Rome.

[26] Bryceson, D. (2000) Rural Africa at the Crossroads: Livelihood Practices and Policies. Natural Resource Perspectives No. 52, Overseas Development Institute (ODI). www.odi.org.uk

[27] Ellis, F. and Freeman, H.A. (2004) Rural Livelihoods and Poverty Reduction Strategies in Four African Countries. Journal of Development Studies, 40, 1-30. http://dx.doi.org/10.1080/00220380410001673175

[28] FAO (2006) The Role of Agriculture and Rural Development in Revitalizing Abandoned/Depopulated Areas. Food and Agriculture Organization of the United Nations, Rome.

[29] Madukwe, M.C., Okoli, E.C. and Eze, S.O. (2002) Analysis and Comparison of the Agricultural Development Programme and University Agricultural Technology Transfer Systems in Nigeria. ATPS Working Paper Series No. 3. www.atpsnet.org/Files/working_paper_series_35

[30] Lanjouw, J.O. and Lanjouw, P. (2001) The Rural Non-Farm Sector: Issues and Evidence from Developing Countries. Agricultural Economics, 261, 1-23. http://dx.doi.org/10.1111/j.1574-0862.2001.tb00051.x

[31] Haq, M. (2003) Human Development in South Asia 2002. Oxford University Press, Karachi, 24.

[32] Gallup, J., Radelet, S. and Warner, A. (1997) Economic Growth and the Income of the Poor. CAER II Discussion Paper No. 36, Harvard Institute for International Development, Boston.

[33] Timmer, P. (1997) How Well Do the Poor Connect to the Growth Process? CAER Discussion Paper No. 178, Harvard Institute for International Development (HIID), Cambridge, MA.

[34] Suryahadi, A., Suryadarma, D. and Sumarto, S. (2009) The Effects of Location and Sectoral Components of Economic Growth on Poverty: Evidence from Indonesia. Journal of Development Economics, 89, 109-117. http://dx.doi.org/10.1016/j.jdeveco.2008.08.003

[35] Christoplos, I. and Kidd, A. (2000) Guide for Monitoring, Evaluation, and Joint Analyses of Pluralistic Extension Support. Neuchâtel Group, Lindau.

[36] Peralta, O.B. (2003) The Role of Financial Sector in Poverty Reduction. UNEP F1 Global Roundtable, Tokyo.

[37] World Bank (2009) From Poor Areas to Poor People: China’s Evolving Poverty Reduction Agenda-An Assessment of Poverty and Inequality in China. Poverty Reduction and Economic Management Department, The World Bank, Washington DC.

[38] World Bank (2001) World Development-Report. Oxford University Press, New York.

[39] ADB (2002) Poverty in Pakistan: Issues, Causes and Institutional Response. Asian Development Bank (ADB)-Pakistan Resident Mission, Islamabad.

[40] Bari, F. (2003) Growth and Poverty Paradox. The Journal, 8, 13-18.

[41] Grewal, B. and Ahmad, A. (2011) International Workshop on the Role of Agriculture in Poverty Reduction. Centre for Strategic Economic Studies Victoria University, Melbourne.

[42] Loayza, N.V. and Raddatz, C. (2010) The Composition of Growth Matters for Poverty Alleviation. Journal of Development Economics, 93, 137-151. http://dx.doi.org/10.1016/j.jdeveco.2009.03.008

[43] Ravallion, M. and Datt, G. (1996) How Important to India’s Poor Is the Sectoral Composition of Economic Growth. World Bank Economic Review, 10, 1-26. http://dx.doi.org/10.1093/wber/10.1.1

[44] Topalova, P.B. (2008) India: Is the Rising Tide Lifting All Boats? IMF Working Paper No. 08/54, International Monetary Fund (IMF), Washington DC.

[45] Virmani, A. (2007) The Sudoku of Growth, Poverty and Malnutrition: Policy Implications for Lagging States. Planning Commission Working Paper No. 2/2007-PC.

[46] Government of Ghana (2010) Ghana Shared Growth and Development Agenda (GSGDA). National Development Planning Commission (NDPC), September 7, 2010.

[47] Chambers, R. (1995) Poverty and Livelihoods: Whose Reality Counts? ID Discussion Paper 347, IDS, Brighton.

[48] Swaminathan, M.S. (1987) Food 2000: Global Policies for Sustainable Agriculture. Report to the World Commission on Environment and Development, Zed Press, London.

[49] Chambers, R. (1987) Sustainable Rural Livelihoods: A Strategy for People, Environment and Development. An Overview Paper for Only One Earth: Conference on Sustainable Development, 28-30 April 1987, IIED, London.

[50] Baumann, P. (2000) Sustainable Livelihoods and Political Capital: Arguments and Evidence from Decentralization and 
Natural Resource Management in India. ODI Working Paper 136, ODI, London.

[51] Hoon, P., Singh, N. and Wanmali, S. (1997) Sustainable Livelihoods: Concepts, Principles and Approaches to Indicator Development. http://www.sustainablelivelihoods.com/pdf/sustainablelivelihoodsc-1.pdf

[52] Scoones, I. (1998) Sustainable Rural Livelihoods: A Framework for Analysis. IDS Working Paper 72, IDS, Brighton.

[53] Nicol, A. (2000) Adopting a Sustainable Livelihoods Approach to Water Projects: Implications for Policy and Practice. ODI Working Paper 133, ODI, London.

[54] Chambers, R. and Conway, G. (1992) Sustainable Rural Livelihoods: Practical Concepts for the 21st Century. IDS Discussion Paper 296, IDS, Brighton.

[55] Ashley, C. and Carney, D. (1999) Sustainable Livelihoods: Lessons from Early Experience. DFID, London.

[56] Carney, D., Ed. (1998) Sustainable Rural Livelihoods: What Contribution Can We Make? DFID, London.

[57] Conway, T., et al. (2012) Rights and Livelihoods Approaches: Exploring Policy Dimensions. Natural Resource Perspectives 78, ODI, London.

[58] Chambers, R. (2008) Revolutions in Development Inquiry. Earth Scan, London.

[59] UNDP (2006) Quoted in World Bank Capacity Development Resource Center, Perspectives and Definitions. UNDP, New York.

[60] CIDA (2006) Quoted in World Bank Capacity Development Resource Center-Perspectives and Definitions. Canadian International Development Agency, Gatineau.

[61] Frank, F. and Smith, A. (1999) The Community Development Handbook. Human Resources Development Canada (HRDC). http://www.hrdc-drhc.gc.ca/community

[62] Horton, D. (2002) Planning, Implementing, and Evaluating Capacity Development. International Service for National Agricultural Research (ISNAR) Briefing Paper 50.

http://portals.wi.wur.nl/files/docs/ppme/capacity_development_isnar.pdf

[63] Horton, D. (1999) Building Capacity in Planning, Monitoring and Evaluation: Lessons from the Field. Knowledge, Technology \& Policy, 11, 152-188. http://www.springerlink.com/content/0488381283516m28/fulltext.pdf http://dx.doi.org/10.1007/s12130-999-1008-2

[64] Fukuda-Parr, S., Lopes, C. and Malik, K., Eds. (2002) Capacity for Development: New Solutions to Old Problems. United Nations Development Programme, New York.

[65] Degnbol-Martinussen, J. (2002) Development Goals, Governance and Capacity Building: Aid as a Catalyst. Development \& Change, 33, 269-279. http://dx.doi.org/10.1111/1467-7660.00253

[66] Government of Punjab (2013) Evaluation Report on Project “Fruits \& Vegetables Development Project”. Directorate General Monitoring and Evaluation, Planning and Development Department, Punjab.

[67] Bartlet, A. (2005) Farmer Field School to Promote Integrated Pest Management in Asia: The FAO Experience. Case Study Presented to the Workshop on Scaling up Case Studies in Agriculture, International Rice Research Institute, 16-18 August 2005, Bangkok.

[68] Van den Bergand, H. and Knols, B.G.J. (2006) The Farmer Field School: A Method for Enhancing the Role of Rural Communities in Malaria Control? Malaria Journal, 5, 3.

[69] Braun, A.R. and Graham, T. (2000) Integrated Nutrient Management to Attain Sustainable Productivity Increase in East African Farming Systems, Kenya, Nairobi.

[70] Matata, J.B.W. and Okech, A.G.O. (1998) Promising and New Methods. Draft Report on New and Adapted Field Methods in Kenya.

[71] Van den Berg, H. (2004) IPM Farmer Field Schools: A Synthesis of 25 Impact Evaluations. Global IPM Facility, Rome.

[72] Luther, G.C., Harris, C., Sherwood, S., Gallagher, K., Mangan, J. and Gamby, K.T. (2005) Chapter 9: Developments and Innovations in Farmer Field Schools and the Training of Trainers. In: Norton, G.W., Heinrichs, E.A., Luther, G.C. and Irwin, M.E., Eds., Globalizing Integrated Pest Management-A Participatory Research Process, Blackwell, Ames.

[73] Farrington, J. and Martin, A. (1988) Farmer Participation in Agricultural Research: A Review of Concepts and Practices. ODA, London.

[74] Bijlmakers, H. (2005) Farmer Field Schools for IPM—Refresh Your Memory, IPM DANIDA.

[75] Rustam, I. (2012) Farmer Field Schools for Improved Agricultural Practices in the Irrigation Zones of Uzbekistan. Central Asian Countries’ Initiative for Land Management (CACILM), Uzbekistan.

[76] Adato, M. and Meinzen-Dick, R. (2002) Assessing the Impact of Agricultural Research on Poverty Using the Sustainable Livelihoods Framework. FCND Discussion Paper 128, EPTD Discussion Paper 89, International Food Policy Re- 
search Institute, Washington DC.

[77] DFID (2000) Sustainable Livelihoods Guidance Sheets. Department for International Development. www.livelihood.org/info/info_guidancesheets.htm 